\title{
Effect of an increase in FSH on the production of gonadotrophin-surge-attenuating factor in women
}

\author{
I. E. Messinis ${ }^{1}$, D. Lolis ${ }^{1}$, K. Zikopoulos ${ }^{1}$, E. Tsahalina ${ }^{2}$, K. Seferiadis ${ }^{2}$ \\ and A. A. Templeton ${ }^{3}$ \\ ${ }^{1}$ Department of Obstetrics and Gynaecology and ${ }^{2}$ Department of Biological Chemistry, \\ University of Ioannina, 45332 Ioannina, Greece; and ${ }^{3}$ Department of Obstetrics and Gynaecology, \\ University of Aberdeen, Aberdeen AB9 2ZD, UK
}

\begin{abstract}
Gonadotrophin-surge-attenuating factor (GnSAF) is a putative nonsteroidal ovarian factor that is produced by FSH and that attenuates the LH surge in superovulated women. To study further the role of FSH in the production of GnSAF, 12 normally ovulating women were divided into two groups and investigated during two cycles: a cycle treated with placebo (control) and a cycle treated with FSH. In group $1(n=6)$, placebo $(2 \mathrm{ml} 0.9 \%$ normal saline) or FSH (450 iu) was injected i.m. on day 2 of the cycle (09:00 h). In group 2 $(n=6)$, placebo ( $2 \mathrm{ml} 0.9 \%$ normal saline) or FSH (225 iu) was injected on the day (09:00 h) on which the dominant follicle was $14-15 \mathrm{~mm}$ in diameter, as measured by ultrasound (i.e. after the pituitary had been primed by endogenous oestrogen for several days). The response of LH over $30 \mathrm{~min}(\Delta \mathrm{LH})$ to an injection of $10 \mu \mathrm{g} L H R H$ i.v. (bioassay for GnSAF in vivo) was investigated once a day in group 1 , and $4,8,12$ and $24 \mathrm{~h}$ after the injection of placebo or FSH in group 2. In group $1, \Delta \mathrm{LH}$ was significantly attenuated $12 \mathrm{~h}$ after treatment with FSH compared with the control cycles, while serum oestradiol concentrations increased $24 \mathrm{~h}$ after the injection of FSH. The decrease in $\triangle \mathrm{LH}$ lasted for the period when the FSH concentation was increased ( 3 days). A significant decrease in the basal concentration of $\mathrm{LH}$ was correlated with the increase in the oestradiol concentration. In group 2, $\Delta \mathrm{LH}$ increased significantly between 4 and $8 \mathrm{~h}$ after treatment (LHRH self-priming effect) in both cycles. However, $\Delta \mathrm{LH}$ was significantly attenuated in the FSH-treated cycles compared with the control cycles after 8,12 and $24 \mathrm{~h}$. At the same time, serum concentrations of oestradiol and immunoreactive inhibin did not change significantly. These results suggest that GnSAF is a nonsteroidal ovarian substance, different from inhibin, the production of which is dependent on FSH and which exerts potent antagonistic effects on the oestradiol-induced self-priming action of LHRH.
\end{abstract}

\section{Introduction}

Several studies in vivo have provided evidence that the ovaries of superovulated women produce a nonsteroidal substance, named gonadotrophin-surge-attenuating factor $(\mathrm{GnSAF})$, that attenuates the endogenous $\mathrm{LH}$ surge by reducing the response of LH to LHRH (Messinis and Templeton, 1989, 1990, 1991a). In these studies, the change in the response of LH to LHRH as a bioassay for GnSAF in vivo has shown that this factor is active during the follicular and the luteal phase of the human menstrual cycle (Messinis and Templeton, 1990; Messinis et al., 1993a). Although GnSAF has not yet been purified, studies in vitro have shown that GnSAF activity is present in steroidfree human follicular fluid and is different from that of inhibin (Busbridge et al., 1990; Fowler et al., 1990; Knight et al., 1990).

Received 14 January 1994
It has been demonstrated that during the early follicular phase of the human menstrual cycle FSH is a potent stimulator of GnSAF production (Messinis et al., 1991, 1993b). An increase in GnSAF bioactivity has been detected as early as $8 \mathrm{~h}$ after a single injection of FSH, that is, before any significant increase in the serum concentration of oestradiol occurs (Messinis et al., 1993b). These data have provided evidence that a threshold concentration of FSH, different from that of oestradiol, is required to stimulate GnSAF production in the early follicular phase of the cycle. It would be interesting, therefore, to study further the relationship between GnSAF activity and FSH with particular reference to the duration of the increase in the concentration of FSH, to clarify the role of FSH in the production of GnSAF. In all studies in which GnSAF bioactivity has been investigated during FSH-superovulated cycles, treatment with FSH began at the onset of the cycle. It is not known, therefore, whether administration of FSH at a later stage during the normal menstrual cycle would also result 
in attenuation of LHRH-induced gonadotrophin secretion. In other words, it is not known whether priming the pituitary with endogenous oestrogen would affect the attenuating effect of GnSAF on LH secretion.

Previous studies investigated the response of LH to small (submaximal) doses of LHRH at different stages during the human menstrual cycle (Wang et al., 1976; Yen and Lein, 1976; Hoff et al., 1977). These studies differentiated between the two functionally related pools of the pituitary gonadotrophs: the pituitary sensitivity (initial release; first pool) and the reserve (integrated response; second pool). Although the concentrations in both pools increase during the follicular phase, the day-to-day variation in the response of LH to LHRH has not been investigated.

The present study attempts a dynamic evaluation of the relationships between the ovaries and the hypothalamicpituitary system by investigating the response of LH to LHRH during the follicular phase with or without FSH treatment.

\section{Materials and Methods}

\section{Patients}

Normally cyclic women $(n=12)$ with longstanding unexplained infertility volunteered for the study and gave written informed consent. The study was approved by the local Ethical Committee. Before the women were admitted to the study, ovulation was confirmed by ultrasound and by measuring the serum concentration of progesterone. The patients were divided into two groups of six women each and were investigated in two menstrual cycles: a cycle treated with placebo (control) and a cycle treated with FSH. After a spontaneous menstrual period, the placebo treatment $(2 \mathrm{ml}$ $0.9 \%$ normal saline) and the FSH treatment [450 iu (i.e. 6 ampoules at 75 iu FSH per ampoule) Metrodin; Serono, Faran, Athens] for group I were given as single injections i.m. on day $2(09: 00 \mathrm{~h})$ of the first and second cycle, respectively. Similarly, in group 2 , the placebo treatment $(2 \mathrm{ml} 0.9 \%$ normal saline) or the FSH treatment (225 iu; 3 ampoules) were injected on the day $(09: 00 \mathrm{~h})$ on which the dominant follicle was 14-15 $\mathrm{mm}$ in diameter, as assessed by ultrasound. In group I, several experiments assessing the response of $\mathrm{LH}$ to an acute injection of $10 \mu \mathrm{g}$ LHRH i.v. were performed during the follicular phase of both cycles. The first such experiment was performed $12 \mathrm{~h}$ after injecting the placebo or FSH treatment; thereafter, these experiments were performed once a day $(09: 00 \mathrm{~h})$ from day 3 of the cycle to the day of the peak concentration of $\mathrm{LH}$ at midcycle. In group 2 , experiments measuring the concentration of $\mathrm{LH}$ in response to injecting $10 \mu \mathrm{g}$ LHRH i.v. were performed four times during each cycle: $4,8,12$ and $24 \mathrm{~h}$ after injecting the placebo or FSH.

Blood samples in relation to each injection of LHRH (time 0) were taken at $-15,0$ and $30 \mathrm{~min}$. The measurement of the $\mathrm{LH}$ concentration $30 \mathrm{~min}$ after LHRH injection (pituitary sensitivity) was taken as the largest increase in $\mathrm{LH}$ concentration, as in previous studies (Messinis et al., 1991, 1993a, 1993b), because at that time the response of LH to a single small (submaximal) dose of LHRH is maximal during both untreated spontaneous and FSH-treated cycles (Wang et al., 1976;
Messinis and Templeton, 1991a). In all blood samples taken during the LHRH experiments the concentration of LH was measured. Basal concentrations (at time 0 and before injecting the placebo or FSH treatments) of FSH and oestradiol in both groups and of inhibin in group 2 were also measured.

\section{Hormone assays}

The concentrations of LH and FSH were measured in serum using immunometric assays based on enhanced luminescence (Amerlite LH-30 assay and Amerlite FSH assay, respectively). Kits were purchased from Amersham International, Amersham. LH kits contained mouse monoclonal anti-whole-LH coated on the wells and mouse monoclonal anti- $\beta$-subunit of LH labelled with horseradish peroxidase. FSH kits contained sheep antiFSH coated on the wells and mouse monoclonal anti-FSH labelled with horseradish peroxidase. The concentrations of $\mathrm{LH}$ are expressed as iu standards $1^{-1}$ calibrated against the WHO Ist IRP of human LH (68/40); those of FSH are expressed as iu standards $1^{-1}$ calibrated against the WHO 2nd IRP of human FSH (78/549).

A solid-phase fluoroimmunoassay was used to measure the concentration of oestradiol; this assay was based on the competition between europium-labelled oestradiol and sample oestradiol for polyclonal anti-oestradiol antibodies (DELFIA Estradiol kit). Kits were purchased from Pharmacia, Wallac Oy, Turku. Oestradiol kits contained rabbit oestradiol antiserum and anti-rabbit immunoglobulin $G$ coated to the solid phase as a second antibody. Concentrations are expressed as pmol $1^{-1}$.

Serum inhibin concentrations were determined using a solid phase two-site immunoenzymetric assay (INHIBIN-EASIA). Kits were purchased from Medgenix Diagnostics, SA, Fleurus; they contained a goat polyclonal antibody coated on the plastic wells and a mouse monoclonal antibody conjugated to peroxidase. Both antibodies recognize distinct epitopes on the $\alpha$ subunit of human inhibin. There is no crossreaction with various growth factors, $\mathrm{LH}, \mathrm{FSH}$ and activin at concentrations up to $100 \mathrm{ng} \mathrm{ml}^{-1}$. Values are expressed as iu $\mathrm{ml}^{-1}$.

The lower limits of detection for $\mathrm{LH}, \mathrm{FSH}$, oestradiol and inhibin were $0.12 \mathrm{iu} 1^{-1}, 0.5 \mathrm{iu} 1^{-1}, 50 \mathrm{pmol} \mathrm{l}^{-1}$ and $0.1 \mathrm{iu} \mathrm{ml} \mathrm{m}^{-1}$, respectively, while interassay and intra-assay coefficients of variation were 9.0 and $6.8 \%, 7.5$ and $6.0 \%, 9.1$ and $8.0 \%$, and 8.8 and $2.9 \%$, respectively.

\section{Statistical analyses}

The results were statistically analysed using one-way analysis of variance. Within the same group of cycles, differences in the concentrations of hormones were assessed using Student's paired $t$ test. The arithmetic means of the hormone concentrations are presented; however, in the statistical calculations these were transformed into logarithms. This was performed to achieve approximate 'normal distribution' of the data.

\section{Results}

In both groups the response of LH to LHRH was calculated as the net increase in the concentration of $\mathrm{LH}(\Delta \mathrm{LH})$ above the basal value. 
Group 1

Basal concentrations of FSH, LH and oestradiol on day 2 of the cycle (mean \pm SEM) did not differ significantly between the control and the FSH-treated cycles (Fig. 1). Administration of FSH to women resulted in a significant increase in serum FSH concentrations from $7.2 \pm 0.5 \mathrm{iu}^{-1}$ before the FSH injection to $18.8 \pm 1.7 \mathrm{iu} \mathrm{l}^{-1}$ and $18.4 \pm 1.6 \mathrm{iu} \mathrm{l}^{-1} 12 \mathrm{~h}$ and $24 \mathrm{~h}$ (day 3 , $09: 00 \mathrm{~h})$ after the injection, respectively $(P<0.001)$. The concentration of FSH was still high on day $4\left(12.3 \pm 0.8 \mathrm{iu} \mathrm{I}^{-1}\right.$, $P<0.001)$. On days 2 ( $12 \mathrm{~h}$ ), 3 and 4 , serum FSH concentrations were significantly higher than in the control cycles, with no significant difference between the two cycles from day 5 onwards. In the control cycles, the highest serum FSH concentrations were observed on day $3\left(7.8 \pm 0.5 \mathrm{iu} \mathrm{l}^{-1}\right)$, and decreased gradually thereafter until day $6(P<0.05)$.

The $\triangle \mathrm{LH}$ response to $\mathrm{LHRH}$ was significantly attenuated in the FSH-treated cycles compared with the control cycles $12 \mathrm{~h}$ after injecting FSH $(P<0.001)$ and on days $3(P<0.01)$, $4(P<0.05)$ and $5(P<0.05)$, with no significant difference between the two cycles from day 6 onwards (Fig. 1). The lowest $\Delta \mathrm{LH}$ value (greatest attenuation) occurred $12 \mathrm{~h}$ after injecting FSH $\left(3.0 \pm 0.6 \mathrm{iu} \mathrm{l}^{-1}\right)$, that is, at the time of the highest concentrations of FSH. As FSH concentrations then declined, $\Delta \mathrm{LH}$ increased gradually up to day $6(P<0.001)$. In the control cycles, $\Delta \mathrm{LH}$ after a transient decrease on day 4 (to $5.8 \pm 0.7$ iu $1^{-1}, P<0.05$ ) increased up to day 6 $\left(8.6 \pm 0.9 \mathrm{iu} \mathrm{I}^{-1}, P<0.05\right)$. In both cycles, $\Delta \mathrm{LH}$ did not alter significantly from day 6 to day 8 . In this study the response of FSH to LHRH was not evaluated owing to the exogenous administration of FSH.

Basal LH and oestradiol concentrations (mean \pm SEM) did not change significantly $12 \mathrm{~h}$ after injecting the placebo or FSH treatments (Fig. 1). Thereafter, the concentration of LH remained stable in the control cycles but decreased significantly in the FSH-treated cycles on days $3\left(2.6 \pm 0.5 \mathrm{iu} \mathrm{l}^{-1}\right), 4$ $\left(2.3 \pm 0.8 \mathrm{iu} \mathrm{I}^{-1}\right)$ and $5\left(2.8 \pm 0.7 \mathrm{iu} \mathrm{l}^{-1}\right)(P<0.01)$. At these points, $\mathrm{LH}$ concentrations were significantly lower than in the control cycles $(P<0.01)$. Serum oestradiol concentrations in the control cycles increased gradually from day 2 to day 8 $(P<0.05)$, while in the FSH-treated cycles they increased rapidly on day $3\left(343 \pm 50 \mathrm{pmol} \mathrm{l}^{-1}\right)$, peaked on day 4 $\left(587 \pm 121 \mathrm{pmol} \mathrm{l}^{-1}\right)$ and were still high, although decreasing, on day $5\left(412 \pm 107 \mathrm{pmol}^{-1}, P<0.05\right)$. At these points the concentrations of oestradiol in the FSH-treated cycles were significantly higher than in the control cycles $(P<0.05$, Fig. 1$)$. Thereafter, serum concentrations of oestradiol did not differ significantly between the two cycles, but increased significantly from day 6 to day $8(P<0.05)$.

Fig. 1. Increase in the concentration of (a) $\mathrm{LH}(\Delta \mathrm{LH})$ in response (over $30 \mathrm{~min}$ ) to $10 \mu \mathrm{g} \mathrm{LHRH}$ (injected once a day), and the serum concentrations of basal (b) FSH, (c) LH and (d) oestradiol during the follicular phase of (O) control (placebo-treated) and (O) FSHtreated cycles following a spontaneous menstrual period in women. Placebo ( $2 \mathrm{ml} 0.9 \%$ normal saline) or FSH (450 iu) was injected i.m. on day 2 of the cycle. Values are means \pm SEM for six women. ${ }^{* * *} P<0.05,{ }^{* *} P<0.01,{ }^{*} P<0.001$ compared with corresponding control cycles.
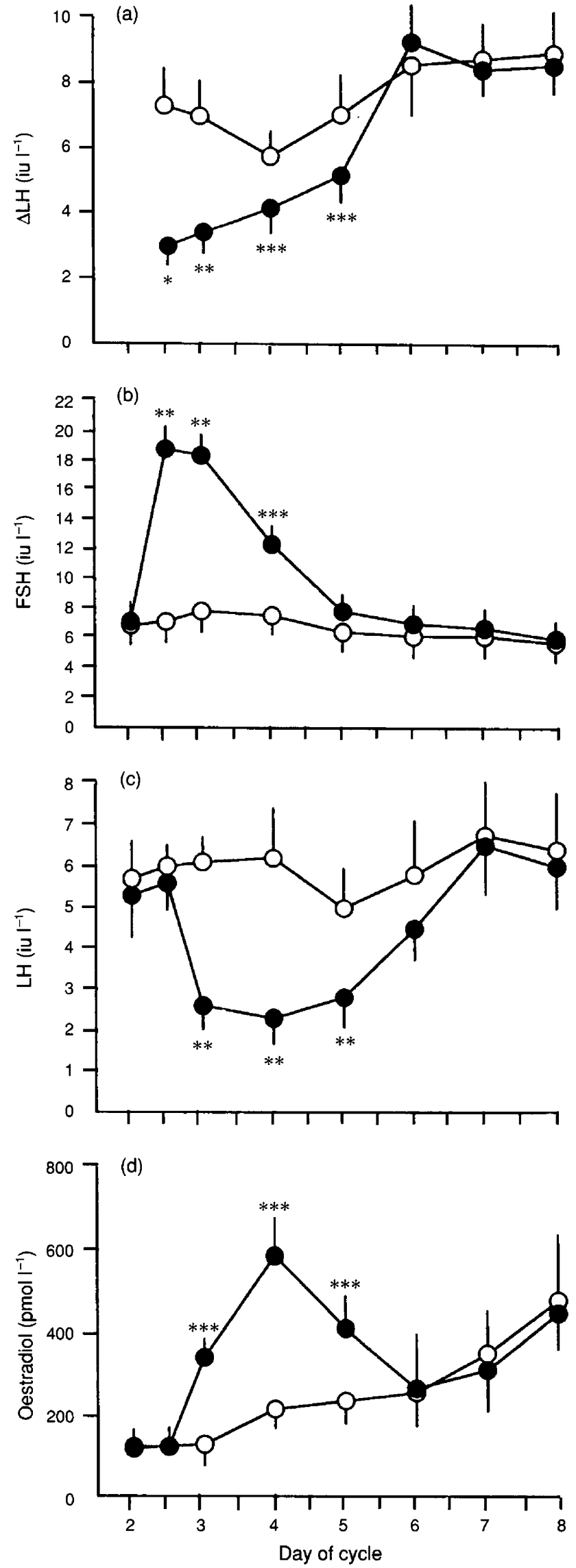

Downloaded from Bioscientifica.com at 04/26/2023 01:42:52PM 

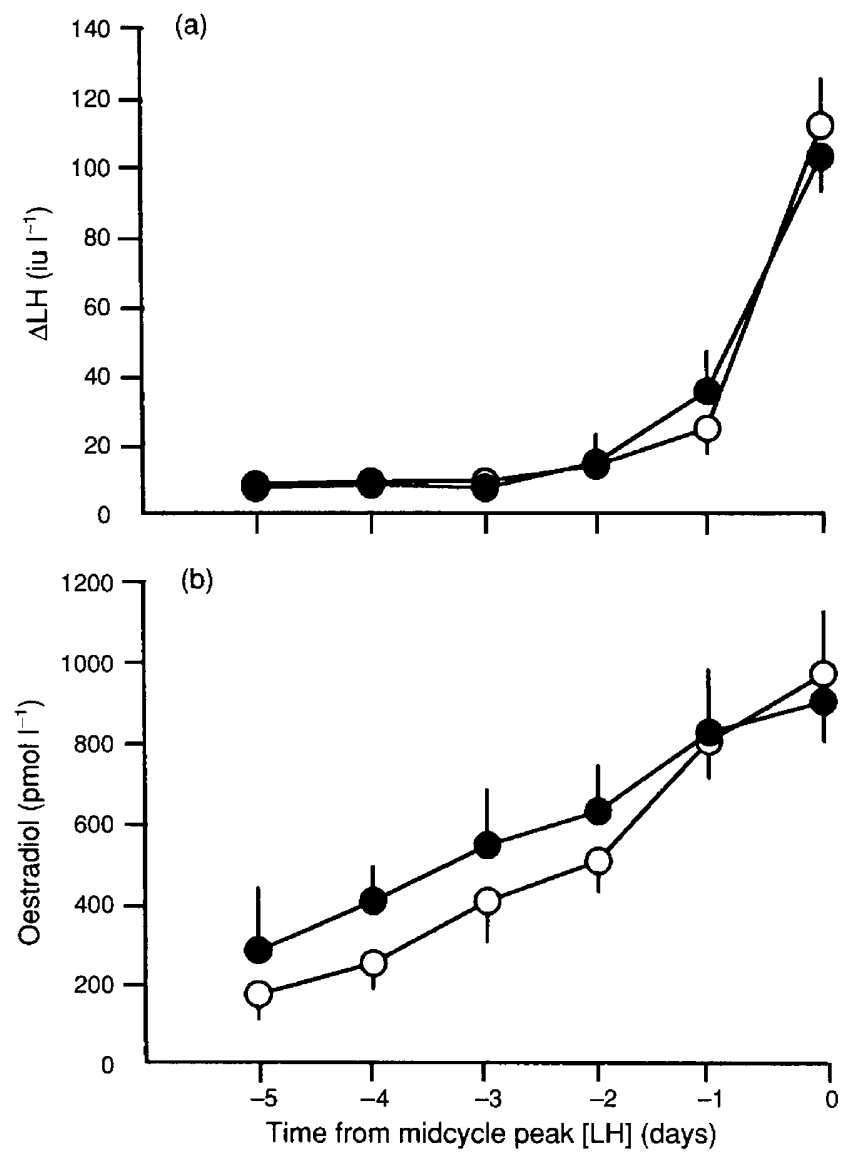

Fig. 2. Increase in the concentration of (a) $\mathrm{LH}(\Delta \mathrm{LH})$ in response (over $30 \mathrm{~min}$ ) to $10 \mu \mathrm{g} \mathrm{LHRH} \mathrm{(injected} \mathrm{once} \mathrm{a} \mathrm{day)} \mathrm{and} \mathrm{(b)} \mathrm{the} \mathrm{serum}$ concentration of basal oestradiol during the second half of the follicular phase of (O) control (placebo-treated) and (O) FSHtreated cycles following a spontaneous menstrual period in women. The results have been normalized to the day of the midcycle LH peak (day 0). Placebo ( $2 \mathrm{ml} 0.9 \%$ normal saline) or FSH (450 iu) was injected i.m. on day 2 of the cycle. Values are means \pm SEM for six women.

$\Delta \mathrm{LH}$ before and during the midcycle peak of $\mathrm{LH}$ concentration were similar in the control and the FSH-treated cycles (Fig. 2). In both cycles, $\Delta \mathrm{LH}$ did not change significantly from days -5 to -3 , but almost doubled between days -3 (control cycle, $9.0 \pm 0.7$; FSH-treated cycle, $7.4 \pm 1.6 \mathrm{iu}^{-1}$ ) and -2 (control cycle, $13.8 \pm 2.1$; FSH-treated cycle, $14.7 \pm 4.8$ iu $\left.\mathrm{I}^{-1}, P<0.05\right)$ and between days -2 and -1 (control cycle on day $-1,24.6 \pm 4.2$; FSH-treated cycle on day $-1,35.6 \pm 8.9$ iu $\left.I^{-1}, P<0.05\right)$. During the time when the LH concentration peaked there was an abrupt increase in $\Delta \mathrm{LH}$ (control cycles, $113 \pm 17.5 ;$ FSH-treated cycles,

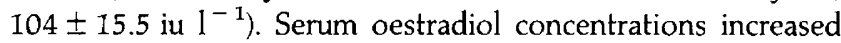
progressively during the 4 days before the peak LH concentration occurred, with no significant difference between the two cycles. The increase in oestradiol concentrations was also significant from days -5 to -3 in both cycles $(P<0.05)$. The concentration of oestradiol peaked on the day that the $\mathrm{LH}$ concentration peaked.

In both cycles, only one follicle $>13 \mathrm{~mm}$ in diameter was detected by ultrasound on the day of the peak LH concen- tration at midcycle. Ovulation of this follicle was confirmed in all women by ultrasound. None of the patients became pregnant during this treatment. However, one woman conceived spontaneously in a subsequent untreated cycle after the study had ended.

\section{Group 2}

Placebo or FSH treatments were given on average on the same day (mean \pm SEM) during the follicular phase of the control (10.5 \pm 0.9 days) and the FSH-treated cycles (10.6 \pm 0.8 days). The size of the leading follicle (mean \pm SEM) on that day was similar in the control $(14.4 \pm 0.1 \mathrm{~mm})$ and the FSH-treated cycles $(14.5 \pm 0.2 \mathrm{~mm})$.

Basal FSH concentrations before treatments were not significantly different between the two cycles (Fig. 3). Serum FSH concentrations increased significantly, 2, 4, 8, 12 and $24 \mathrm{~h}$ after injecting FSH and were significantly higher than those in the control cycles. Peak values occurred after $8 \mathrm{~h}$ $\left(12.9 \pm 0.4 \mathrm{iu}^{-1}\right)$. A significant increase in the serum concentration of FSH was also observed in the control cycles between $4 \mathrm{~h}\left(3.6 \pm 0.2 \mathrm{iu} \mathrm{l}^{-1}\right)$ and $12 \mathrm{~h}\left(6.1 \pm 1.0 \mathrm{iu} \mathrm{l}^{-1}, P<0.05\right)$ after treatment, decreasing thereafter. Four hours after the injection, $\triangle \mathrm{LH}$ was similar in the control and the FSH-treated cycles ( $14.6 \pm 1.2$ and $13.5 \pm 2.1$ iu $\mathrm{l}^{-\mathrm{T}}$, respectively). In both cycles, $\Delta \mathrm{LH}$ increased significantly between 4 and $8 \mathrm{~h}$ and decreased between 8 and $12 \mathrm{~h}$, increasing again significantly up to $24 \mathrm{~h}$ after treatment $(P<0.05)$. However, an increase in $\triangle \mathrm{LH}$ was significantly attenuated in the FSH-treated cycles compared with the control cycles at $8 \mathrm{~h} \quad(19.5 \pm 2.6$ versus $30.6 \pm 3.2$ iu $\left.l^{-1}, P<0.01\right)$, $12 \mathrm{~h}$ ( $10.5 \pm 1.1$ versus $19.2 \pm 1.8$ iu $\left.1^{-1}, P<0.05\right)$ and $24 \mathrm{~h}(20.1 \pm 2.8$ versus

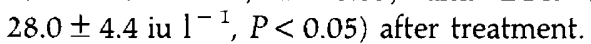

Basal LH and oestradiol concentrations before the treatment were similar in the two cycles (Fig. 3). During the time when the response of $\mathrm{LH}$ to $\mathrm{LHRH}$ was being measured, the basal concentration of $\mathrm{LH}$ increased significantly in both cycles between 4 and $8 \mathrm{~h}(P<0.01)$, followed by a gradual decrease thereafter. The increase, however, was greater in the FSHtreated cycles at 8 and $12 \mathrm{~h}(P<0.01)$. Serum oestradiol concentrations did not change significantly during the LHRH experiments in both cycles. Serum concentrations of immunoreactive inhibin were similar in the two cycles before and during the GnRH injections, with no significant change observed from the onset to the end of the experimental period (Fig. 3).

All women displayed an LH surge in both cycles within 2-3 days after injecting the placebo or FSH treatment. Only one follicle $>13 \mathrm{~mm}$ in diameter was detected by ultrasound on the day of the LH surge. Ovulation was confirmed in all patients by ultrasound. None of the patients became pregnant during this treatment.

\section{Discussion}

The present study demonstrates that a marked attenuation in the response of LH to LHRH occurs within $12 \mathrm{~h}$ after administering a single injection of a high dose of FSH on the second 

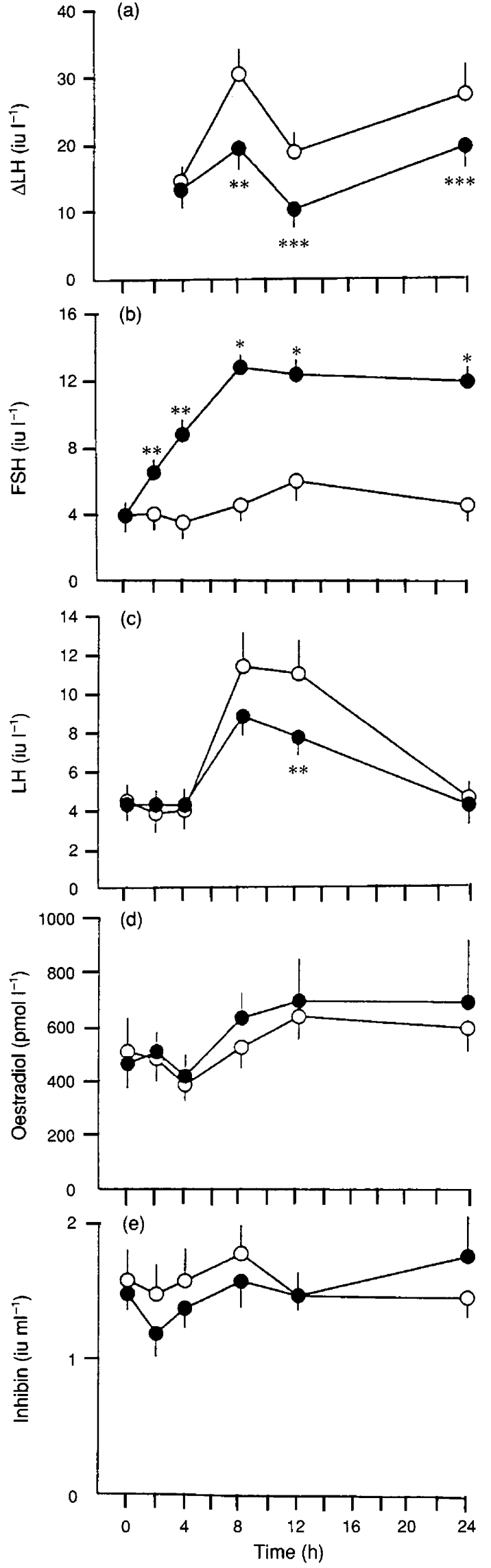

day of a spontaneous menstrual cycle. This attenuation is in agreement with data from previous studies, and confirms the role of FSH in the stimulation of GnSAF production in women (Messinis et al., 1991, 1993b). The possibility that the attenuation was caused by an increase in the concentrations of oestrogen is excluded, as in previous studies (Messinis et al., 1991, 1993b), by the fact that it occurred before any significant increase in the serum concentration of oestradiol was observed. It is clear, therefore, that GnSAF and oestradiol are two different entities. The fact that the increase in GnSAF bioactivity after injecting 450 iu FSH in the early follicular phase lasted for the period of FSH increase suggests that, under the present experimental conditions, GnSAF production depends on FSH. In contrast to $\triangle \mathrm{LH}$, the pattern of change in the basal LH concentrations correlated inversely with the change in the oestradiol concentrations, thus confirming previous evidence that the basal secretion of $\mathrm{LH}$ during the early follicular phase is under the negative influence of oestradiol (Messinis and Templeton, 1989; Messinis et al., 1993b). In addition, the fact that basal LH concentrations decreased at a time when $\Delta \mathrm{LH}$ was increasing indicates that oestradiol can suppress the basal secretion of $\mathrm{LH}$ through mechanisms not involving hypothalamic LHRH.

A significant increase in GnSAF bioactivity was also seen in this study when FSH was injected during the late follicular phase of the cycle; that is after the pituitary had been primed by endogenous oestrogen for about 10 days. Oestradiol is known to play a crucial role in inducing the self-priming effect of LHRH on the pituitary; this effect can be detected experimentally, during the injection of multiple LHRH pulses, as an enhanced response of gonadotrophin to the second LHRH pulse given $2 \mathrm{~h}$ after the first pulse (Lasley et al., 1975; Wang et al., 1976). The self-priming effect was also evident in the present study, even though in this case LHRH was injected every $4 \mathrm{~h}$. In superovulated cycles, in which FSH is given on a daily basis, GnSAF attenuates the self-priming action of LHRH on the pituitary (Messinis and Templeton, 1991a). The present study further demonstrates that treatment with FSH can induce a significant attenuation in LHRH-stimulated LH secretion, even after the pituitary has been primed by oestrogen. It is possible, therefore, that GnSAF exerts a potent antagonistic effect on oestradiolenhanced pituitary sensitivity to LHRH.

The extent to which various ovarian nonsteroidal substances, such as inhibin, follistatin and activins, can affect LHRH-induced LH secretion in vivo is difficult to assess. Information regarding the effects of these substances on gonadotrophin secretion is mainly derived from studies in vitro; their physiological importance is therefore obscure (Burger,

Fig. 3. Increase in the concentration of (a) $\mathrm{LH}(\Delta \mathrm{LH})$ in response (over $30 \mathrm{~min}$ ) to $10 \mu \mathrm{g}$ LHRH (injected after $4,8,12$ and $24 \mathrm{~h}$ ), and the serum basal concentrations (before each LHRH injection) of (b) $\mathrm{FSH}$, (c) LH, (d) oestradiol and (e) immunoreactive inhibin after the injection (time 0) of (O) $2 \mathrm{ml} 0.9 \%$ normal saline as placebo or (O) $225 \mathrm{iu}$ FSH in the late follicular phase of two different spontaneous cycles of the same women. Values are means \pm SEM for six women. ${ }^{* * *} P<0.05,{ }^{* *} P<0.01,{ }^{*} P<0.001$ compared with corresponding control cycles. 
1992). The present results show that injecting FSH during the late follicular phase of the cycle attenuates the response of $\mathrm{LH}$ to LHRH, while at the same time the concentration of immunoreactive inhibin does not change significantly. This suggests that GnSAF is different from inhibin. However, it should be taken into consideration that free $\alpha$ subunits of inhibin may also be measured in the inhibin assay. So far, several studies in vitro have demonstrated that GnSAF activity, different from that of inhibin, can be detected in steroid-free human follicular fluid (Busbridge et al., 1990; Fowler et al., 1990; Knight et al., 1990). In addition, preliminary data have shown that GnSAF has a molecular mass in the range of $10-30 \mathrm{kDa}$ (Fowler et al., 1992). Follicular fluid fractions containing GnSAF activity do not affect basal FSH or LH secretion in vitro, but only attenuate the response of LH to LHRH (Fowler et al., 1990). It is probable, therefore, that GnSAF is a separate factor in the follicular fluid with the ability to affect gonadotrophin secretion. Nevertheless, even if GnSAF is found to be similar to, or part of, the molecule of one of the nonsteroidal ovarian substances mentioned above, the present as well as previous in vivo data concerning the attenuation of the response of LH to LHRH are interesting because they provide evidence for a nonsteroidal 'ovarian activity' that (at least under experimental conditions) plays a role in the control of gonadotrophin secretion. A recent study has demonstrated that FSH given to postmenopausal women does not affect LHRH-induced LH secretion (Messinis et al., 1994). This provides strong evidence that treatment with FSH attenuates LHRH-induced LH secretion through a mechanism dependent on a functional ovary, which supports the GnSAF hypothesis.

The present study provides a dynamic evaluation of the sensitivity of the pituitary to LHRH during the whole follicular phase of the cycle. It is clear that apart from a transient decrease on day 4 of the control cycles, probably due to changes in the steroidal milieu during the intercycle phase (Messinis et al., 1993c), pituitary sensitivity to LHRH remained unchanged and increased significantly only during the midcycle period, despite the steady rise in the concentration of oestradiol from the early to late follicular phase. The abrupt increase in pituitary sensitivity to LHRH at midcycle has also been reported in previous studies, although the response of $\mathrm{LH}$ to LHRH had been investigated only sporadically during the follicular phase (Wang et al., 1976; Yen and Lein, 1976; Hoff et al., 1977).

An explanation of these findings is difficult. It has been proposed that during the follicular phase of the cycle oestradiol impedes pituitary sensitivity to LHRH (Hoff et al., 1977). This is based on experimental data showing that exogenous administration of oestrogen to hypogonadal women results in a reduction or no alteration in the pituitary sensitivity to LHRH and an increase in the pituitary reserve (Lasley et al., 1975; Quyyumi et al., 1993). However, when the serum concentration of oestradiol increases rapidly during the early follicular phase of the cycle after exogenous administration, it enhances pituitary sensitivity to LHRH (Lasley et al., 1975). In spite of this, in the present study, rapidly rising concentrations of endogenous oestradiol after treatment with FSH did not correlate with changes in pituitary sensitivity. These data tend to suggest that during the human menstrual cycle oestradiol may not be the only regulator of the pituitary response to LHRH. It is possible that GnSAF is involved. The results provide some support for a hypothesis (Messinis and Templeton, 1991b) that during the early to midfollicular phase of the cycle GnSAF maintains the pituitary in a state of low responsiveness to LHRH. However, during the preovulatory period a decrease in the activity of GnSAF facilitates the stimulating effect of oestradiol and results in maximal gonadotrophin secretion.

In conclusion, the present study demonstrates that a marked attenuation in the response of LH to LHRH is induced by increased concentrations of FSH during the follicular phase of the cycle. The attenuation is not related to changes in oestradiol and inhibin concentrations and is not prevented by priming the pituitary with endogenous oestrogen. It is suggested that GnSAF is a nonsteroidal ovarian substance, different from inhibin, the production of which depends on FSH and which exerts potent antagonistic effects on the oestradiol-induced self-priming action of LHRH.

The authors thank O. Tsolas, Director of the Department of Biological Chemistry, University of Ioannina, for providing the laboratory facilities for the hormone assays.

\section{References}

Burger HG (1992) Inhibin Reproductive Medicine Review 1 1-20

Busbridge N, Chamberlain GVP, Griffiths A and Whitehead SA (1990) Nonsteroidal follicular factors attenuate the self-priming action of gonadotrophin-releasing hormone on the pituitary gonadotroph Neuroendocrinology 51 493-499

Fowler PA, Messinis IE and Templeton AA (1990) Inhibition of LHRH-induced $\mathrm{LH}$ and FSH release by gonadotrophin surge-attenuating factor (GnSAF) from human follicular fluid Joumal of Reproduction and Fertility 90 587-594

Fowler PA, Townsend C, Messinis IE, Cunningham P and Templeton A (1992) Gonadotrophin surge-attenuating factor attenuates in-vitro $\mathrm{LH}$ secretion induced by gonadotrophin-releasing hormone from cultured pituitary cells only during the breeding season Journal of Endocrinology 135 221-227

Hoff JD, Lasley BL, Wang CF and Yen SSC (1977) The two pools of pituitary gonadotropin: regulation during the menstrual cycle Journal of Clinical Endocrinology and Metabolism 44 302-312

Knight PG, Lacey M, Peter JLT and Whitehead SA (1990) Demonstration of a nonsteroidal factor in human follicular fluid that attenuates the self-priming action of gonadotropin-releasing hormone on pituitary gonadotropes Biology of Reproduction 128 403-410

Lasley BL, Wang CF and Yen SSC (1975) The effects of estrogen and progesterone on the functional changes of the gonadotrophs Journal of Clinical Endocrinology and Metabolism $41820-826$

Messinis IE and Templeton AA (1989) Pituitary response to exogenous LHRH in superovulated women Journal of Reproduction and Fertility 87 633-639

Messinis IE and Templeton A (1990) In-vivo bioactivity of gonadotrophin surge attenuating factor (GnSAF) Clinical Endocrinology 33 213-218

Messinis IE and Templeton A (1991a) Attenuation of gonadotrophin release and reserve in superovulated women by gonadotrophin surge attenuating factor (GnSAF) Clinical Endocrinology 34 259-263

Messinis IE and Templeton AA (1991b) Evidence that gonadotrophin surgeattenuating factor exists in man Joumal of Reproduction and Fertility 92 $217-223$

Messinis IE, Hirsch P and Templeton AA (1991) Follicle stimulating hormone stimulates the production of gonadotrophin surge attenuating factor (GnSAF) in vivo Clinical Endocrinology 35 403-407

Messinis IE, MacTavish A and Templeton AA (1993a) Activity of gonadotrophin surge-attenuating factor during the luteal phase in superovulated women Joumal of Reproduction and Fertility $97271-275$ 
Messinis IE, Lolis D, Papadopoulos L, Tsahalina Th, Papanikolaou N, Seferiadis K and Templeton AA (1993b) Effect of varying concentrations of follicle stimulating hormone on the production of gonadotrophin surge attenuating factor (GnSAF) in women Clinical Endocrinology 39 45-50

Messinis IE, Koutsoyannis D, Milingos S, Tsahalina E, Seferiadis K, Lolis D and Templeton AA (1993c) Changes in pituitary response to GnRH during the Iuteal-follicular transition of the human menstrual cycle Clinical Endocrinology 38 159-163

Messinis IE, Lolis D, Papastergiopoulou L, Milingos S, Tsahalina E, Seferiadis K and Templeton AA (1994) Effect of follicle stimulating hormone treatment on the pituitary response to luteinizing hormone releasing hormone in postmenopausal women Human Reproduction 9 241-244
Quyyumi SA, Pinkerton JV, Evans WS and Veldhuis JD (1993) Estradiol amplifies the amount of luteinizing hormone (LH) secretion in response to increasing doses of gonadotropin-releasing hormone by specifically augmenting the duration of evoked LH secretory events and hence their mass Journal of Clinical Endocrinology and Metabolism 76 594-600

Wang CF, Lasley BL, Lein A and Yen SSC (1976) The functional changes of the pituitary gonadotrophs during the menstrual cycle Journal of Clinical Endocrinology and Metabolism 42 718-728

Yen SSC and Lein A (1976) The apparent paradox of the negative and positive feedback system on gonadotropin secretion American Journal of Obstetrics and Gynecology $126942-954$ 